\title{
JAKOŚĆ RZĄDZENIA W KRAJACH TRANSFORMUJĄCYCH SIĘ
}

\section{WSTĘP}

W literaturze przedmiotu panuje konsensus, że bez odpowiedniego otoczenia instytucjonalnego działanie bodźców rynkowych nie prowadzi do optymalnej alokacji zasobów ${ }^{1}$. Ponadto wiele badań nad długookresowym wzrostem gospodarczym, prowadzonych m.in. przez D. Rodrika, A. Subramaniana i F. Trebbi², a także D. Acemoglu, S. Johnsona i J. A. Robinsona ${ }^{3}$ oraz W. Easterly, R. Levine ${ }^{4}$, potwierdza, że zmiany instytucjonalne są najważniejszą determinantą wzrostu gospodarczego ${ }^{5}$. W szczególności mają one wielkie znaczenie w przypadku krajów transformujących się. Zmiana instytucjonalna jest bowiem jednym $z$ trzech obszarów dokonującej się transformacji gospodarczej (obok stabilizacji makroekonomicznej i liberalizacji mikroekonomicznej), który pod pewnymi względami nr 1.

${ }^{1}$ Por. A. Wojtyna, Nowe kierunki badań nad ekonomiczna rola państwa, „Ekonomista” 2001,

${ }^{2}$ D. Rodrik, A. Subramanian, F. Trebbi, Institutions Rule: The Primacy of Institutions over Integration and Geography in Economic Development, IMF Working Paper, WP/02/189; D. Rodrik, A. Subramanian, The Primacy of Institutions (and what this does and does not mean), „Finance \& Development", June 2003.

${ }^{3}$ D. Acemoglu, S. Johnson, J. A. Robinson, Reversal of Fortune: Geography and Institutions in the Making of the Modern World Income Distribution, „The Quarterly Journal of Economics”, November 2002; iidem, The Colonial Origins of Comparative Development: An Empirical Investigation, „The American Economic Review” 2001, vol. 91, no. 5.

${ }^{4}$ W. Easterly, R. Levine, Tropics, germs, and crops: how endowments influence economic development, „Journal of Monetary Economics” 2003, vol. 50, no. 1.

${ }^{5}$ Nie wszyscy zgadzają się z tym wnioskiem. Jednym z głównych przeciwników tego stwierdzenia jest J. D. Sachs, który wskazuje na nadrzędny wpływ geografii na tempo wzrostu gospodarczego i rozwój instytucji. Por. J. D. Sachs, Institutions Don't Rule: Direct Effects of Geography on Per Capita Income, „NBER Working Paper” 2003, no. 9490; J. L. Gallup, J. D. Sachs, A. Mellinger, Geography and Economic Development, Center for International Development at Harvard University, CID Working Paper, no. 1, 1999. 
- jak wskazują m.in. M. Dewatripont i G. Roland ${ }^{6}$ - jest najważniejszy. Badania nad wzrostem w okresie transformacji potwierdzają, że instytucje są, obok polityki stabilizacji i liberalizacji, najważniejszą zmienną wpływającą na jego tempo ${ }^{7}$.

Problemem podjętym w artykule jest pytanie o konwergencję instytucjonalną w krajach transformujących się. Czy pod względem jakości rządzenia zbliżają się one czy oddalają od państw wysoko rozwiniętych? Celem artykułu jest analiza zmian jakości rządzenia w krajach transformujących się i ocena dystansu wobec krajów OECD o wysokim dochodzie. Analizie poddanych zostanie sześć zmiennych składających się na jakość rządzenia (governance). Są to: głos obywateli i rozliczalność rządzących (voice and accountability), stabilność polityczna i brak przemocy (political stability $\Xi$ absence of violence/terrorism), efektywność rządów (government effectiveness), jakość regulacji (regulatory quality), rządy prawa (rule of law) i kontrola korupcji (control of corruption). Przedmiotem analizy będzie 27 krajów transformujących się z Europy Środkowej i Wschodniej oraz byłego ZSRR. Źródłem danych będzie baza Worldwide Government Indicators "Governance Matters”. Okres analizy obejmuje lata 1996-2008. Do stwierdzenia, czy instytucje w krajach transformujących się zbliżają się do tych z OECD, zostanie użyta metoda wzorca.

\section{ZNACZENIE INSTYTUCJ PAŃSTWA}

Od lat 90. w wielu pracach wskazuje się na instytucje państwa jako jedną z głównych determinant poziomu produkcji i długookresowego wzrostu gospodarczego ${ }^{8}$. Wyrazem tej tendencji jest włączanie instytucji do modeli wzrostu jako

${ }^{6}$ M. Dewatripont, G. Roland, Transition as a process of large-scale institutional change, „Economics of Transition" 1996, no. 1, s. 2.

${ }^{7}$ Podsumowanie wyników badań znaleźć można w: I. Babetskii, N. F. Campos, Does Reform Work? An Econometric Examination of the Reform-Growth Puzzle, The Institute for the Study of Labor (IZA), Discussion Paper, no. 2638, 2007; N. F. Campos, F. Coricelli, Growth in transition: what we know, what we don't, and what we should, "Journal of Economic Literature", September 2002; E. Falcetti, T. Lysenko, P. Sanfey, Reforms and growth in transition: Re-examining the evidence, "Journal of Comparative Economics” 2006, no. 34; O. Havrylyshyn, Recovery and growth in transition: a decade of evidence, IMF Staff Papers, no. 48, 2001; O. Havrylyshyn, R. van Rooden, Institutions matter in transition, but so do policies, IMF Working Paper 2000, WP/00/70; B. Merlevede, Growth in transition economies. A review of the literature, http://www.econ.kuleuven. ac.be/licos/DP/DP2000/DP93.pdf (7.02.2007).

${ }^{8}$ R. E. Hall, C. I. Jones, Why do some countries produce so much more output per worker than others?, „Quarterly Journal of Economics” 1999, vol. 144, no. 1; D. C. North, Structure and Change in Economic History, W. W. Norton \& Co., New York 1981; D. Rodrik, Where has all the Growth Gone? External Shocks, Social Conflict, and Growth Collapses, „Journal of Economic Growth” 1999, no. 4; S. Djankov, R. La Porta, F. Lopez-de-Silanes, A. Shleifer, Courts, „Quarterly Journal of Economics" 2003, vol. 118, no. 2. 
jednej ze zmiennych endogenicznych. $Z$ długookresowych analiz wynika, iż kraje, które miały sprawniej działające instytucje państwa, są obecnie bardziej rozwinięte i mają wyższy poziom $\mathrm{PKB}$ per capita, a istnienie odpowiednich instytucji jest warunkiem wejścia na ścieżkę konwergencji ${ }^{9}$.

Instytucje państwa mogą wpływać pozytywnie lub negatywnie na wzrost gospodarczy.,Dobre” rozwiązania instytucjonalne - poprzez obniżenie kosztów transakcyjnych i barier wejścia na rynek oraz efektywne funkcjonowanie mechanizmu rynkowego - promują aktywność gospodarczą, innowacyjność i działania zwiększające produkcję ${ }^{10}$. Umożliwiają tym samym efektywne funkcjonowanie i rozwój przedsiębiorstw ${ }^{11}$. „Złe” instytucje powodują, że energia podmiotów skierowana jest na zachowania nieefektywne w skali całej gospodarki (rent-seeking, korupcja), co przyczynia się do stagnacji gospodarczej i niedorozwoju ekonomicznego.

Właściwe rozwiązania instytucjonalne są szczególnie istotne w krajach słabo rozwiniętych oraz przechodzących transformację gospodarczą. Doświadczenia tych państw wskazują, że bez odpowiedniego otoczenia instytucjonalnego reformy gospodarcze - mające na celu ograniczenie inflacji, zrównoważenie finansów publicznych, ograniczenie nierównowagi w wymianie handlowej z zagranicą oraz liberalizację warunków prowadzenia działalności gospodarczej - nie przynoszą oczekiwanych rezultatów, a często są po prostu skazane na porażkę ${ }^{12}$.

Znaczenie instytucji w krajach transformujących się jest niezwykle istotne przynajmniej z kilku względów. Zmiana instytucji jest przecież - obok stabilizacji makroekonomicznej i liberalizacji mikroekonomicznej - jednym z obszarów dokonującej się transformacji ${ }^{13}$, a badania nad wzrostem gospodarczym w okre-

${ }^{9}$ S. Johnson, A. Subramanian, Aid, Governance, and the Political Economy: Growth and Institutions, paper prepared for the Seminar on Foreign Aid and Macroeconomic Management, Chissano Conference Center, Maputo, March 14-15, 2005, http://www.imf.org/external/np/seminars/eng/2005/famm/pdf/johnso.pdf, s. 10 (4.11.2008).

${ }^{10}$ Por. M. Bennedsen, N. Malchow-Møller, F. Vinten, Institutions and Growth - a Literature Survey, Centre for Economic and Business Research, Report 1, 2005, s. 10-11; D. A. Grigorian, A. Martinez, Quality of Institutions. What Do (Transition) Economies Have to Gain form the Rule of Law?, The World Bank, Europe and Central Asia Region, Private and Financial Sectors Development Unit, Policy Research Working Paper, no. 2475, 2000, s. 4.

${ }^{11} \mathrm{O}$ wadze rozwiązań prawnych i instytucjonalnych funkcjonowania przedsiębiorstw świadczą m.in. badania H. de Soto i wyniki raportów Doing Business, publikowanych przez World Bank. Szerzej: H. de Soto, Tajemnica kapitatu, Fijoł Publishing, Chicago-Warszawa 2002; Doing Business 2004. Regulacje i ich znaczenie, World Bank, Fundacja Ius et Lex, Warszawa 2004; Doing Business in 2006. Creating Jobs, World Bank. Por. także S. Djankov, C. McLiesh, R. Ramalho, Regulation and Growth, The World Bank, March 17, 2006.

${ }^{12} \mathrm{~J}$. Ahrens, Toward a Post-Washington Consensus: The Importance of Governance Structures in Less Developed Countries and Economies in Transition, „Journal for Institutional Innovation, Development and Transition” 2000, no. 4, s. 2.

${ }^{13}$ L. Balcerowicz, Socjalizm, kapitalizm, transformacja. Szkice zprzetomu epok, Wydawnictwo Naukowe PWN, Warszawa 1997, s. 179. 
sie transformacji wskazują, że zmiany instytucji są istotną determinantą zmian wielkości produkcji. Biorąc pod uwagę skrajnie różne cechy gospodarki centralnie zarządzanej i rynkowej, należy stwierdzić, że transformacja gospodarcza wymaga ogromnych zmian instytucjonalnych ${ }^{14}$. Dotyczą one również roli państwa w gospodarce, w kontekście której zwraca się w literaturze uwagę na „paradoks przystosowującego się państwa" (paradox of the adjusting state) ${ }^{15}$. Paradoks ten dotyczy roli państwa w gospodarce, które z jednej strony musi wycofać się z pełnionych $\mathrm{w}$ poprzednim ustroju gospodarczym funkcji, a $z$ drugiej powinno być na tyle silne i efektywne, żeby realizować zadania wynikające $z$ transformacji, tj. stabilizować gospodarkę, liberalizować warunki działalności gospodarczej, prywatyzować przedsiębiorstwa i zmieniać otoczenie instytucjonalne.

\section{ZMIANY JAKOŚCI RZĄDZENIA W KRAJACH TRANSFORMUJĄCYCH SIĘ}

Istotna rola państwa $\mathrm{w}$ transformacji gospodarczej uzasadnia zwrócenie szczególnej uwagi na jakość rządzenia (governance) w krajach transformujących $\operatorname{się}^{16}$.W literaturze można odnaleźć wiele definicji tego pojęcia ${ }^{17}$. Po przeprowadzeniu krytycznej analizy J. Ahrens zaproponował następującą definicję jakości rządzenia ${ }^{18}$ : jest to zdolność formalnego i nieformalnego otoczenia instytucjonalnego (w którym działają zarówno gospodarstwa domowe, przedsiębiorstwa, grupy społeczne, organizacje pozarządowe, jak i rząd odpowiedzialny za politykę gospodarczą) do wdrażania i zapewnienia przestrzegania polityki gospodarczej oraz poprawy koordynacji w działalności gospodarczej sektora prywatnego. Liczne ba-

${ }^{14}$ M. Bałtowski, M. Miszewski, Transformacja gospodarcza w Polsce, Wydawnictwo Naukowe PWN, Warszawa 2006, s. 25.

${ }^{15} \mathrm{~J}$. Ahrens, Toward a Post-Washington Consensus..., s. 9.

${ }^{16} \mathrm{Na}$ temat zmian, jakie musiały zajść w sferze rządzenia podczas transformacji, por.: E. Rice, Managing the transition. Enhancing the efficiency of Eastern European governments, The World Bank Working Papers, no. 757, 1991; A. Shleifer, Government in transition, „European Economic Review" 1997, no. 41.

${ }^{17}$ Por. np.: J.-J. Dethier, Governance and Economic Performance: A Survey, ZEF, Discussion Papers on Development Policy, no. 5, Bonn 1999, s. 5; J. S. Hellman, G. Jones, D. Kaufmann, M. Schankerman, Measuring Governance, Corruption, and State Capture. How Firms and Bureaucrats Shape the Business Environment in Transition Economies, The World Bank and European Bank for Reconstruction and Development, Policy Research Working Paper, no. 2312, 2000, s. 2-3; R. Nowak, Transparency and good governance in transition economies, paper presented to the Preparatory Seminar for the Ninth OSCE Economic Forum, Almaty, 2-3 November, 2000, s. 2.

${ }_{18} \mathrm{~J}$. Ahrens, Governance, conditionality and the transformation of post-socialist countries, [w:] H. W. Hoen (ed.), Governance structures in Central and Eastern Europe, CESS Harmonie Paper Special Issue, 2000, s. 47. 
dania empiryczne wskazują, że jakość rządzenia wywiera istotny wpływ na tempo wzrostu gospodarczego i poziom produkcji ${ }^{19}$, a nawet zadowolenie $\mathrm{z} \dot{z} y c i a^{20}$.

Mierzenie jakości instytucji, także jakości rządzenia, stwarza pewne trudności. Wynikają one z jednej strony z dość szerokiego zakresu tego pojęcia, a z drugiej są spowodowane przez to, że jakość rządzenia jest zmienną nieobserwowalną. Wnioskowanie na temat poziomu jakości rządzenia musi więc odbywać się na podstawie obserwacji pewnych zjawisk. W artykule posłużono się danymi na temat jakości rządzenia publikowanymi przez Bank Światowy w serii raportów pt. Governance Matters, a udostępnianymi w bazie danych Worldwide Government Indicators „Governance Matters”21. Okres analizy to lata 1996-2008. Badane kraje transformujące się, zgodnie ze stosowaną praktyką, podzielono na grupy ze względu na postęp transformacji gospodarczej. Wykorzystano przy tym podział zaproponowany przez Europejski Bank Odbudowy i Rozwoju, w serii raportów Transition Report. Kraje transformujące swoje gospodarki dzielone są na trzy grupy: Europa Środkowowschodnia i kraje bałtyckie ${ }^{22}$, Europa Południowowschodnia $^{23}, \mathrm{WNP}^{24}$.

Bank Światowy definiuje jakość rządzenia (governance) jako tradycje i instytucje, poprzez które sprawowana jest władza w kraju, a zalicza do nich: proces wyboru, kontroli i zmiany władz; zdolność władz do efektywnego formułowania i wdrażania właściwej polityki; szacunek obywateli i władz dla instytucji, które

${ }^{19} \mathrm{H}$. W. Hoen, Taking stock on transformation: market reform and democratization in Central and Eastern Europe, [w:] H. W. Hoen (ed.), Governance structures in Central and Eastern Europe, CESS Harmonie Paper Special Issue, 2000; S. Knack, Governance and Growth: Measurement and Evidence, University of Maryland, Center for Institutional Reform and the Informal Sector, IRIS Discussion Papers on Institutions \& Development, no. 5, 2002; M. Olson, N. Sarna, A. V. Swamy, Governance and Growth: A Simple Hypothesis Explaining Cross-country Differences in Productivity Growth, University of Maryland, Center for Institutional Reform and the Informal Sector, IRIS Working Paper, no. 218, 1998; F. Rivera-Batiz, Democracy, governance and economic growth: theory and evidence, http://www.columbia.edu/cu/economics/discpapr/DP0102-57.pdf (15.10.2007). P. Tridico stwierdza nawet, że różnice w poziomie rozwoju między wschodnią a zachodnią częścią Polski są wynikiem różnic w jakości rządzenia. P. Tridico, Institutional Change and Governance Indexes in Transition Economies: the case of Poland, „The European Journal of Comparative Economics" 2006, no. 2, s. 198.

${ }^{20} \mathrm{~J}$. F. Helliwell, H. Huang, How's your government? International evidence linking good government and well-being, „NBER Working Paper” 2006, no. 11988.

${ }^{21}$ Zaletą danych z Banku Światowego jest to, że badania nad jakością rządzenia nie miały charakteru jednorazowego, ale są cyklicznie prowadzone - najpierw co dwa lata $(1996,1998$, 2000, 2002), a od 2003 r. corocznie.

${ }^{22}$ Czechy, Estonia, Litwa, Łotwa, Polska, Słowacja, Słowenia i Węgry.

${ }^{23}$ Albania, Bośnia i Hercegowina, Bułgaria, Chorwacja, Macedonia, Rumunia i Serbia. W skład tej grupy powinna wejść również Czarnogóra, ale ze względu na brak danych nie wzięto jej pod uwagę w badaniu.

${ }_{24}$ Armenia, Azerbejdżan, Białoruś, Gruzja, Kazachstan, Kirgistan, Mołdawia, Rosja, Tadżykistan, Turkmenistan, Ukraina i Uzbekistan. 
wyznaczają ramy ich gospodarczych i społecznych relacji ${ }^{25}$. Na podstawie tej definicji jakość rządzenia analizowana jest w sześciu obszarach: głos obywateli i rozliczalność rządzących, stabilność polityczna i brak przemocy, efektywność rządów, jakość regulacji, rządy prawa i kontrola korupcji, z których pierwsze dwa charakteryzują proces wyboru, kontroli i zmiany władz, kolejne dwa zdolność władz do efektywnego formułowania i wdrażania właściwej polityki, a ostanie dwa szacunek obywateli i władz dla instytucji. Wartość maksymalna wskaźnika w każdym z sześciu obszarów to 2,5 , a minimalna $-2,5$. Im wyższa wartość, tym lepsza jest jakość rządzenia.

Zmiany jakości rządzenia w krajach transformujących się przedstawiono na wykresie 1.

Głos obywateli i rozliczalność rządzących mierzy wpływ obywateli kraju na wybór władz, oraz wolność słowa, stowarzyszania się i wolność mediów. Zarówno w tym obszarze jakości rządzenia, jak i w pozostałych kraje Europy Środkowowschodniej i kraje bałtyckie osiągają najlepsze wyniki, a kraje WNP najgorsze. W badanym okresie tylko państwa Europy Południowowschodniej w znaczący sposób polepszyły swój wynik w tym obszarze, natomiast kraje WNP zanotowały spadek tego wskaźnika. Ten obszar jakości rządzenia jest również obszarem, w którym państwa WNP osiągnęły swój najgorszy wynik z sześciu obszarów jakości rządzenia, a kraje Europy Południowowschodniej odnotowały tutaj swój najlepszy wynik.

Stabilność polityczna i brak przemocy mierzy postrzeganie prawdopodobieństwa destabilizacji lub obalenia rządu w sposób niekonstytucyjny lub przy użyciu przemocy. We wszystkich grupach krajów przechodzących transformację zanotowano w badanym okresie poprawę tego wskaźnika, przy czym w krajach WNP w latach 1996-2004 zmniejszał się on, żeby w kolejnych latach szybko wzrosnąć. Miało to związek z tak zwanymi „kolorowymi rewolucjami”, które doprowadziły do zmiany władz w Gruzji w 2003 roku („rewolucja róż”), na Ukrainie w 2004 roku („pomarańczowa rewolucja”) i w Kirgistanie w 2005 roku („rewolucja tulipanów”). Stabilność polityczna i brak przemocy jest jednocześnie tym obszarem jakości rządzenia, w którym kraje WNP w roku 2008 osiągnęły swój najlepszy wynik.

Efektywność rządów mierzy jakość usług publicznych, jakość służby cywilnej i stopień jej niezależności od presji politycznej, jakość procesu formułowania i wdrażania polityki oraz wiarygodność zobowiązania władz do jej realizacji. W tym obszarze we wszystkich grupach krajów przechodzących transformację następowała w badanym okresie powolna poprawa.

${ }^{25}$ D. Kaufmann, A. Kraay, P. Zoido-Lobatón, Governance Matters, The World Bank, Development Research Group Macroeconomics and Growth, World Bank Institute Governance, Regulation and Finance Policy Research Working Paper, no. 2196, 1999, s. 1. 

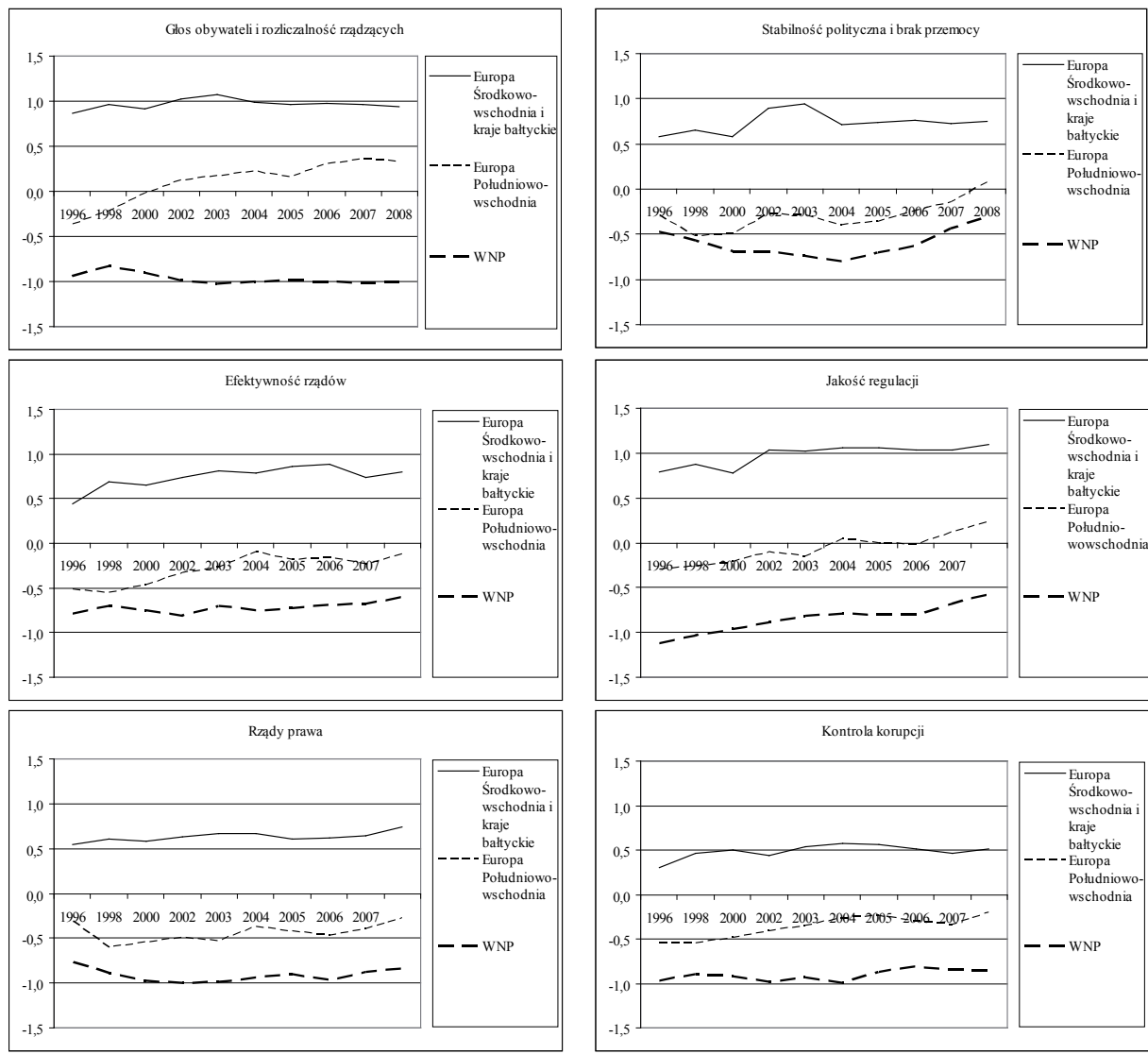

Wykres 1. Jakość rządzenia w krajach transformujących się w latach 1996-2008

Źródło: opracowanie własne na podstawie danych Worldwide Government Indicators „Governance Matters", http://www. govindicators.org.

Jakość regulacji mierzy zdolność rządu do formułowania i wdrażania właściwej polityki oraz regulacji, które umożliwiają i ułatwiają rozwój sektora prywatnego. Również w tym obszarze odnotowano poprawę w trzech analizowanych grupach krajów. Była ona większa niż w obszarze efektywność rządów, a szczególnie duża w państwach WNP (średni wskaźnik tej grupy krajów wzrósł z -1,12 do -0,58). Jakość regulacji to również obszar, w którym kraje Europy Środkowowschodniej i kraje bałtyckie w roku 2008 osiągnęły swój najlepszy wynik ze wszystkich sześciu obszarów jakości rządzenia.

Rządy prawa to obszar jakości rządzenia, w którym mierzone jest zaufanie podmiotów do policji i sądów, a także reguł społecznych oraz ich przestrzeganie, w szczególności w odniesieniu do realizacji kontraktów. Ponadto brane jest również pod uwagę prawdopodobieństwo popełnienia przestępstw i gwałtów. 
W badanym okresie sytuacja w tym obszarze nie była jednoznaczna. Kraje Europy Środkowowschodniej i kraje bałtyckie poprawiły swoje wyniki, ale w państwach WNP sytuacja pod tym względem pogorszyła się, a w krajach Europy Południowowschodniej, mimo że wskaźnik rządów prawa nieznacznie wzrósł, to jednak osiągnęły one swój najgorszy wynik ze wszystkich sześciu obszarów jakości rządzenia.

Kontrola korupcji mierzy zakres, w jakim władza publiczna jest wykorzystywana do osiągania prywatnych korzyści, a także zakres „zawładnięcia” państwem przez elity i grupy interesu. W tym obszarze następowała $\mathrm{w}$ badanym okresie poprawa sytuacji, szczególnie zauważalna w krajach Europy Południowowschodniej. Był to też obszar, w którym w roku 2008 kraje Europy Środkowowschodniej i kraje bałtyckie odnotowały swój najgorszy wynik.

\section{ODLEGŁOŚĆ OD WZORCA}

W celu porównania dystansu między krajami transformującymi się a państwami OECD o wysokim dochodzie posłużono się metodą odległości od wzor$\mathrm{ca}^{26}$, będącą sposobem liniowego porządkowania zbioru obiektów ${ }^{27}$. Metoda ta opiera się na zmiennych syntetycznych, w stosunku do których ustala się wzorzec $^{28}$, czyli obiekt modelowy charakteryzujący się pożądanymi cechami. „W metodach wzorcowych zakładamy istnienie obiektu wzorcowego, w którym zmienne wejściowe przyjmują optymalne wartości. Wartości zmiennych wejściowych dla obiektu wzorcowego mogą być ustalane na podstawie ogólnie przyjętych norm, opinii ekspertów oraz na podstawie obserwacji ich wartości w porządkowanych obiektach"29.

Obliczając dystans w zakresie wybranych wskaźników instytucjonalnych, należy wybrać wzorzec kraju spełniającego określone cechy. Możliwe są trzy wzorce:

1) wirtualnego kraju, który łączy najwyższe możliwe (optymalne) wartości indeksów;

${ }^{26}$ Podobnie jak w pracach: P. Janowski, Warunki prowadzenia dziatalności gospodarczej. Jak daleko Europie Środkowowschodniej do liderów?? [w:] L. Zienkowski (red.), Co sprzyja rozwojowi gospodarczemu, Wydawnictwo Naukowe Scholar, Warszawa 2005, s. 61-82; A. B. Czyżewski, M. Kolasa, „Knowledge Economy” - jak daleko Polsce do Unii Europejskiej?, [w:] L. Zienkowski (red.), Wiedza a wzrost gospodarczy, Wydawnictwo Naukowe Scholar, Warszawa 2003.

${ }^{27}$ Szerzej na temat metod porządkowania obiektów por. T. Panek, Statystyczne metody wielowymiarowej analizy porównawczej, Oficyna Wydawnicza SGH, Warszawa 2009, s. 57-104.

${ }^{28}$ Pionierem metod wzorcowych był Z. Hellwig, Zastosowanie metody taksonomicznej do typologicznego podziatu krajów ze względu na poziom ich rozwoju oraz zasoby i strukture wykwalifikowanych kadr, „Przegląd Statystyczny” 1968, z. 4, s. 307-327.

${ }^{29}$ T. Panek, op. cit., s. 58. 
2) wirtualnego kraju, który łączy najkorzystniejsze faktycznie osiągnięte wartości indeksów;

3) kraju (względnie grupy państw) odnotowującego przeciętne najlepsze wielkości wskaźników rozwoju instytucjonalnego.

$\mathrm{Na}$ potrzeby niniejszego badania przyjęto jeden wzorzec, tj. średnią dla krajów OECD o wysokim poziomie dochodu ${ }^{30}$. Uzasadnieniem tego wyboru jest fakt, że jest to grupa krajów najwyżej rozwiniętych i charakteryzujących się wysoką jakością rządzenia, do której aspirują kraje transformujące się. W badaniu zastosowano miarę odległości miejskiej o zmodyfikowanej formie:

$$
d(x, y)=\sum_{i}\left(x_{i}-y_{i}\right)
$$

gdzie $x$ i $y$ to wartości indeksów odpowiednio dla przyjętego wzorca oraz badanego kraju. Zmodyfikowanej formy odległości miejskiej używa się wówczas, gdy badany obiekt może być lepszy niż wzorzec ${ }^{31}$.

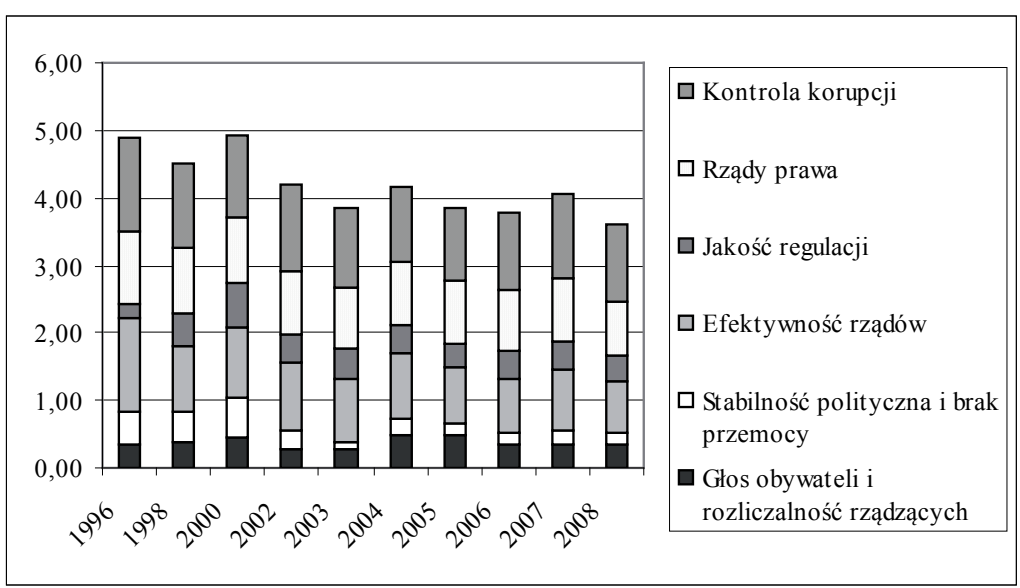

Wykres 2. Odległość państw Europy Środkowowschodniej i krajów bałtyckich od średniej dla krajów OECD pod względem jakości rządzenia w latach 1996-2008

Źródło: opracowanie własne na podstawie danych Worldwide Government Indicators "Governance Matters", http://www. govindicators.org.

${ }^{30}$ Zgodnie z definicją Banku Światowego są to: Australia, Austria, Belgia, Dania, Finlandia, Francja, Grecja, Hiszpania, Holandia, Irlandia, Islandia, Japonia, Kanada, Korea Poludniowa, Luksemburg, Niemcy, Norwegia, Nowa Zelandia, Portugalia, Stany Zjednoczone, Szwajcaria, Szwecja, Wielka Brytania, Włochy oraz Czechy, Słowacja i Węgry, których jednak ze względu na cel badania nie wliczono do średniej.

${ }^{31}$ P. Janowski, op. cit., s. 64. 
Wykres 2 (zob. s. 285) przedstawia odległość państw Europy Środkowowschodniej i krajów bałtyckich od krajów OECD. Odległość ta zmniejszyła się (z 4,9 do 3,61), jednak w badanym okresie podlegała ona silnym wahaniom. Najmniejsza odległość występuje w odniesieniu do procesu wyboru, kontroli i zmiany władz, czyli w obszarach: głos obywateli i rozliczalność rządzących oraz stabilność polityczna i brak przemocy, a w latach 1996-2008 jeszcze się ona zmniejszyła. Zmniejszenie różnic było widoczne również w odniesieniu do efektywności rządów, ale różnica w jakości regulacji - chociaż niewielka - zwiększyła się. W obszarach rządy prawa i kontrola korupcji zmniejszyła się odległość od krajów OECD, ale jednocześnie w tych właśnie obszarach była ona największa.

Jak wynika z danych przedstawionych na wykresie 3, również odległość krajów Europy Południowowschodniej od państw OECD uległa w badanym okresie zmniejszeniu, a od roku 2000 obserwujemy jej systematyczne zmniejszanie. Ponadto odległość zmniejszyła się we wszystkich obszarach jakości rządzenia, najbardziej w odniesieniu do efektywności rządów. Państwa tej grupy, podobnie jak kraje Europy Środkowowschodniej i państwa bałtyckie, mają najmniejszą odległość od krajów OECD w obszarach odnoszących się do procesu wyboru, kontroli i zmiany władz, a największą pod względem szacunku obywateli i władz dla instytucji, które wyznaczają ramy ich gospodarczych i społecznych relacji (rządy prawa i kontrola korupcji).

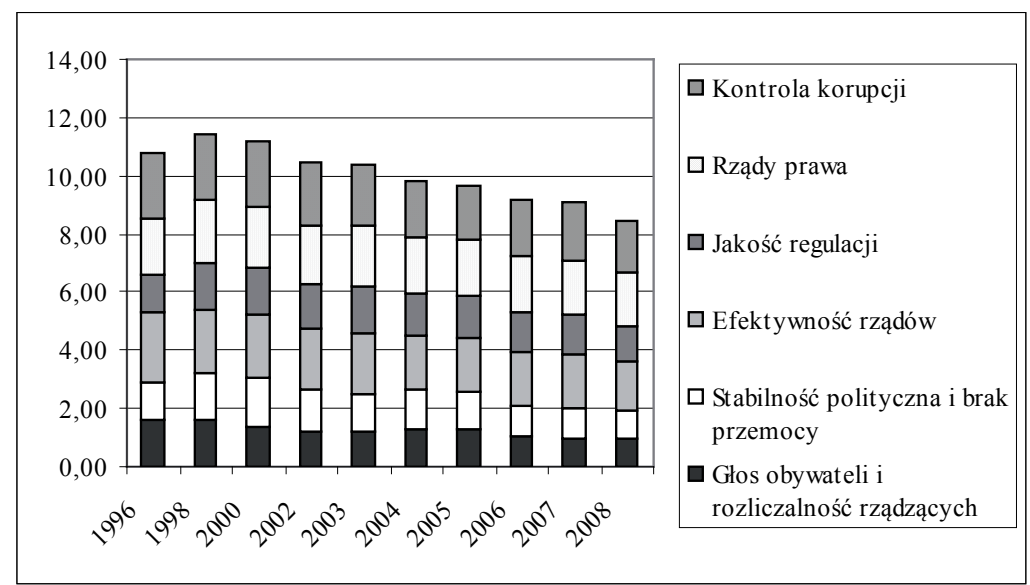

Wykres 3. Odległość państw Europy Południowowschodniej od średniej dla krajów OECD pod względem jakości rządzenia w latach 1996-2008

Źródło: opracowanie własne na podstawie danych Worldwide Government Indicators „Governance Matters", http://www. govindicators.org. 
Na wykresie 4 przedstawiono dane charakteryzujące odległość państw WNP od krajów OECD. Oczywiście, odległość ta jest znacznie większa niż w przypadku wcześniej analizowanych grup krajów transformujących się. W latach 1996-2004 zwiększała się ona, a później, aż do 2008 roku, zmniejszała się, tak że na końcu badanego okresu jej poziom był niższy niż na początku. Nie we wszystkich obszarach jakości rządzenia nastąpiła poprawa. Odległość od krajów OECD zwiększyła się pod względem głosu obywateli i rozliczalności rządzących oraz rządów prawa. Największa odległość występowała w odniesieniu do rządów prawa i kontroli korupcji (czyli podobnie jak w pozostałych grupach państw), ale na podobnym poziomie była ona również w obszarze głos obywateli i rozliczalność rządzących. Zdecydowanie najmniejsza odległość wystąpiła pod względem stabilności politycznej i braku przemocy.

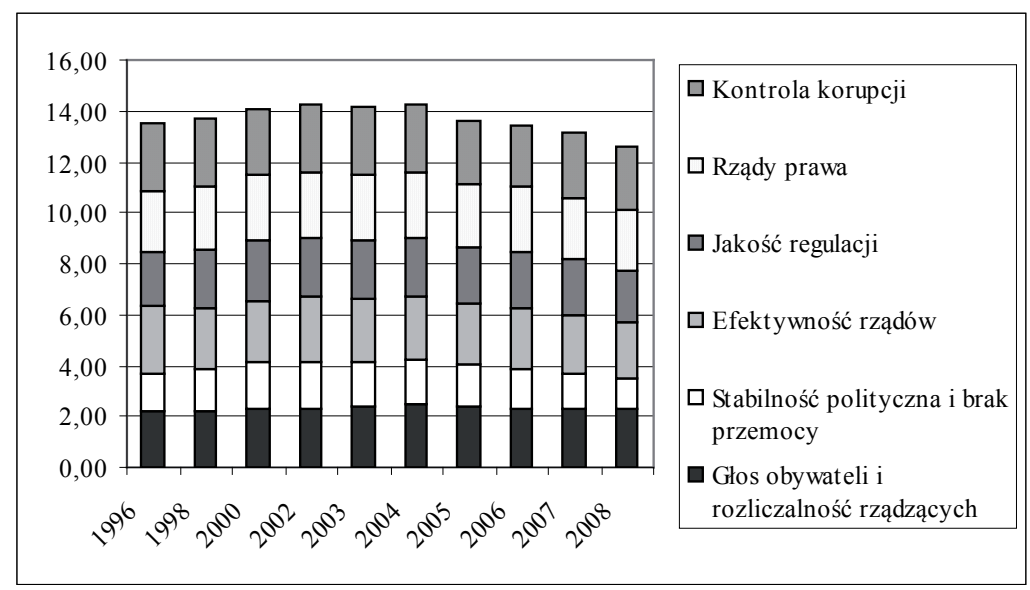

Wykres 4. Odległość państw WNP od średniej dla krajów OECD pod względem jakości rządzenia w latach 1996-2008

Źródło: opracowanie własne na podstawie danych Worldwide Government Indicators "Governance Matters", http://www. govindicators.org.

\section{ZAKOŃCZENIE}

Przeprowadzona analiza pozwoliła na sformułowanie następujących wniosków.

1. Najbardziej zbliżone do krajów OECD pod względem jakości rządzenia są kraje Europy Środkowowschodniej i kraje bałtyckie. Najmniej zaawansowana pod tym względem jest transformacja w krajach WNP. 
2. W badanym okresie następowała konwergencja instytucjonalna krajów Europy Środkowowschodniej i krajów bałtyckich oraz państw Europy Południowowschodniej do państw OECD.

3. Kraje WNP w badanym okresie tylko w niewielkim stopniu zbliżyły się do krajów OECD, a poprawa jakości rządzenia była niewielka.

4. Państwa Europy Środkowowschodniej i kraje bałtyckie oraz Europy Południowowschodniej mają największe problemy w obszarach jakości rządzenia charakteryzujących szacunek obywateli i władz dla instytucji, które wyznaczają ramy ich gospodarczych i społecznych relacji (rządy prawa i kontrola korupcji). Najmniejsza różnica występuje natomiast w odniesieniu do procesu wyboru, kontroli i zmiany władz, czyli w obszarach: głos obywateli i rozliczalność rządzących oraz stabilność polityczna i brak przemocy.

5. W państwach WNP największa różnica w porównaniu do krajów OECD występuje - podobnie jak w pozostałych grupach państw przechodzących transformację - w odniesieniu do rządów prawa i kontroli korupcji. Jednak również w obszarze głos obywateli i rozliczalność rządzących dystans dzielący kraje WNP od OECD jest znaczący. Z tej przyczyny wydaje się, że najmniejsza różnica, która ma miejsce w obszarze stabilność polityczna i brak przemocy, nie może stanowić powodu do satysfakcji. Prawdopodobnie oznacza ona wyłącznie, że reżimy polityczne, które nie słuchają głosu swoich obywateli, są jednocześnie na tyle silne, że nie ma perspektyw na zmianę władzy.

\section{THE QUALITY OF GOVERNANCE IN TRANSITION COUNTRIES}

\section{SUMMARY}

The purpose of this paper is to analyze changes in governance in transition countries and to evaluate their distance from high-income OECD countries. Six variables that impinge on governance were analyzed.

According to many authors institutions are the most important determinant of longterm economic growth, especially in transition countries. Institutional changes are one of three main areas of economic transition (the others are macroeconomic stabilization and microeconomic liberalization). Economic research on economic growth during economic transition confirms that institutions with stabilization and liberalization are the most important determinants.

The conclusions of this paper are that in Central Eastern Europe and the Baltic states and in South Eastern Europe there is institutional convergence. However, the Commonwealth of Independent States in the analyzed period only slightly shortened their distance from OECD countries. 